\title{
SYNTAX MENTIONED SEVEN TIMES IN THE CEFR - AND HOW MANY TIMES AT SCHOOL, IN FOREIGN LANGUAGE CLASSROOMS?
}

\section{INTRODUCTION}

Complex-clause syntax is regarded in this paper as comprising linguistic structures composed of a principal clause and one or more explicit or implicit subordinate clauses (hypotactic clauses) and two or more coordinate clauses (paratactic clauses). To date, in the era of the communicative approach not much is known scientifically about the role of complex-clause syntax in foreign/second language (=FL/L2) classrooms, in particular from the learners' viewpoint. In order to bridge this research gap, the paper analyses a questionnaire among 17- to 18-year-old learners in the third year of secondary schools that looked at their perspectives on the (possible) role of syntax. The examined aspects concern its role for the four skills, and the benefits of knowing syntax - implicitly including also some affective factors - and methodological approaches related to the teaching of syntax.

In the teaching of foreign languages, complex-clause syntax does not seem to have had an established role over the last 20 years, especially not within the communicative approach and the Common European Framework for Languages (CEFR 2001). Previously, it was taken into account by methods which stressed formal approaches to foreign language teaching, but not by natural, acquisition-based methods. Two important premises were introduced by the communicative approach (and they have been acknowledged by the CEFR): authentic texts and grammar as a tool when necessary. This is one probable reason why explicit, complex-clause syntax is hardly mentioned in the CEFR, even though it is implicitly present in descriptors, even though it is particularly recognisable in those for writing skills, and even though we know that it can be used for all four skills, as well as to guide learners towards some self-directed learning about language features.

The two main research questions this article addresses, by employing a quantitative research method, i.e. through an analysis of seven research statements in a questionnaire about learners' attitudes and perceptions about complex-clause syntax, are, first, its importance for the development of the four skills, especially the productive ones, and, second, the learners' attitudes to possible methodological approaches for explicitly or implicitly dealing with it. Aspects to be explored implicitly are learners' perceptions

* Author's address: Filozofska fakulteta, Univerza v Ljubljani, Aškerčeva 2, 1000 Ljubljana, Slovenia. E-mail: darja.mertelj@guest.arnes.si. 
of the possible benefits or disadvantages of the explicit learning of complex-clause syntax in the FL classroom.

\subsection{Syntax in the Common European Framework for Languages}

Two main streams have permeated the history of FL/L2 learning and teaching: a) the natural approach, with the idea of practical use of the language in question; and b) the grammatical approach, with the idea of a thorough study of the constituents of the language. The goal of both was to enhance learners' ability to use the FL, and complex-clause syntax was present in both a) as part of formulaic language (which served as an input that became an intake in acquisition processes), and b) as part of the grammatical system to be learned consciously and, when necessary, transferred to use in the FL (cf. Vučo 2012).

By considering Batstone's distinction (1994: 5) between grammar as a product (i.e. a list of topics about individual grammar structures) and grammar as a process (i.e. grammar as a tool for processing the language), one can recognise that both are also reflected in the CEFR (2001, 5.2.1.2.: 123-124). This fact implies that grammar is an important element of linguistic competence since, even though it is not explicitly addressed in the descriptors, it is also not specifically omitted:

Syntax deals with the organisation of words into sentences in terms of the categories, elements, classes, structures, processes and relations involved, often presented in the form of a set of rules. The syntax of the language of a mature native speaker is highly complex and largely unconscious. The ability to organise sentences to convey meaning is a central aspect of communicative competence (CEFR 2001, 5.2.1.2.: 123-124).

As seen in the above quotation, the syntax of a native speaker is highlighted, particularly its "unconsciousness" (and at the same time its correctness, compared to that of learners of an FL/L2 at lower levels), and including its central role in FL/L2 communication. Later, syntax is only mentioned again where methodological aspects of foreign language learning from learners' perspectives are presented (CEFR 2001, 6.2.2: 149):

6.2.2 How do learners learn? [...] but that learning is facilitated, especially under artificial classroom conditions, by a combination of conscious learning and sufficient practice to reduce or eliminate the conscious attention paid to low-level physical skills of speaking and writing as well as to morphological and syntactic accuracy, thus freeing the mind for higher-level strategies of communication (CEFR 2001: 149).

Elsewhere in the CEFR, syntax is merely named or listed without being elaborated; however, it appears to be "scattered" across quite a few chapters of the CEFR: within orthographic control ("to deal with syntactic ambiguity", CEFR 2001: 127), it is always listed among the aims ("knowledge of its phonetic system, its vocabulary and syntax", CEFR 2001: 145), and it is included in the observation and analysis of learner errors ("syntactic errors and mistakes", CEFR 2001: 165), while also being mentioned in connection with the linguistic complexity of oral or written texts (CEFR 2001: 174): 
[...] particularly complex syntax consumes attentional resources that might otherwise be available for dealing with content; for example, long sentences with a number of subordinate clauses, non-continuous constituents, multiple negation, scope ambiguity, use of anaphorics and deictics without clear antecedents or reference. Syntactic over-simplification of authentic texts, however, may actually have the effect of increasing the level of difficulty (because of the elimination of redundancies, clues to meaning etc.) [...] (CEFR 2001: 174).

It is interesting that the importance of syntax is mentioned in the concluding chapter about different scenarios for teaching an FL, but it also appears to be worth mentioning for the primary school level, where it is presented as being important for construing the basic foundations of an FL (CEFR 2001: 185): “[...] establishing the beginnings of a basic linguistic component, primarily phonetic and syntactic aspects, while promoting elementary oral interaction in class" (CEFR 2001: 185).

However, it cannot be assumed that complex-clause syntax is irrelevant even though it is not explicitly considered or dealt with. In other parts of the CEFR, syntax is often implicitly present and recognisable, since we cannot exclude its role where general descriptors of levels are presented in the columns specified for language accuracy and coherence (CEFR 2001, 3.4.: 50-51). The two aspects of accuracy and coherence are prominent especially in the chapter on the productive abilities: speaking (oral descriptions, oral monologue, public speaking and forms of spoken interaction with others, cf. CEFR 2001, 4.4.3.: 97-106) and writing (creative, reports, essays and, again, written interaction with others, cf. CEFR 2001, 4.4.3.: 106-107).

Yet the Common European Framework for Languages (2001) does not provide answers to specific language teaching questions in (individual or common) cases of particular languages. Although the common descriptors for each level seem to be clear and give evident indications (also for grammatical structures), it is well known that they are "recognised, interpreted and/or understood" in different ways. There have been doubts in Slovenian schools over the last few years about how to address this issue: in fact, it is only on the basis of the national curricula (which fully adopt the CEFR) and textbooks for various foreign/second languages published in Europe that some agreement has been reached on the grammatical structures to be taught at each level, although without much reflection on which structure and to what extent.

\subsection{Syntax in applied linguistics research}

Some recent studies on syntactic complexity state (Vyatkina 2012) or seem to (re) confirm (Ortega 2012, cited in Vyatkina 2012) that this area is largely underexplored, but it appears that the topic has been (rarely) reappearing recently for some languages studied as first, second and foreign languages (examples: for German - Schlobinski 2014, for English and Chinese - Lu 2011, for German as an FL for specific purposes - Höppnerovà 2013). Studies focus on the developmental profiling of the interlanguage, including syntax, but it is especially research for lower levels of proficiency that has largely been neglected. In her research, Vyatkina (2012: 25) shows that specific 
complexity measures for higher proficiency levels also emerge at the beginners' levels, where some of her learners predominantly maintained coordination, but others also developed more complex syntactic structures.

Vyatkina seems to (re)confirm - as far as the implications for teaching are concerned - that instruction has a great influence on learners' performance: learners should be explicitly taught how to use linguistic features, and teachers should go beyond presenting the rules and should aim to achieve specific communicative purposes (Byrnes et al. 2010, in Vyatkina 2012). The same authors also propose a focus on syntactic features by means of examples associated with a level-appropriate writing task that is to be completed by learners (Byrnes et al. 2010). Some other authors not only suggest focussing on syntactic structures and their contextual use and functions, but suggest model texts that involve the targeted structures, and raise awareness of the importance of noticing linguistic features in learners' and model texts (cf. also Bostič 2011).

As far as corpus-based research on complex-clause syntax is concerned, some recent studies propose moving beyond word-based analyses to focus more on linguistic and syntactic patterns (Granger 2009). Further, a project is being developed (for English as an FL/L2) that will draw links between the Cambridge Learner Corpus and the CEFR (Hawkins and McCarthy 2010); here, also syntactic features in learner-produced texts and their level according to the CEFR are to be examined.

With a view to fostering the development of all four language skills, and in line with key issues about learners' language awareness (van Lier 2001; Bolitho et al. 2003), it is believed that the systematic and explicit development of knowledge about complexclause syntax might also be important for learners. On the other hand, there are also drawbacks which suggest that "comprehensible input" (according to Krashen's input hypothesis, this is acquired "by understanding language that contains structure/s a bit beyond our current level of competence $(i+1)$ ", Krashen 1982: 21) is the only necessary condition for developing the language towards higher levels of proficiency. This, however, has not been substantiated by research results.

\subsection{Syntax and applied linguistics of Romance languages vs. Slavic languages}

From the linguistic point of view, there are quite a few, mainly contrastive, studies concerning teaching Italian and Spanish complex-clause syntax to Slovenian students (for Italian, see Miklič 1992, 2003; Miklič and Ožbot 2007; Lenassi 2004; for Spanish, see Markič 2006; cf. Correia et al. 2013 for Portuguese), or to learners with a Serbian or a Croatian linguistic background (Samardžić 2006). Slavic learners share persistent difficulties, including these three aspects:

a) recognising the suitable syntactic pattern in their first/main language (L1, mostly mother tongue) and realising which should be used in their FL production, in consideration of the appropriate clause patterns and connectives;

b) choosing the appropriate tense and/or mood in subordinate clauses in which concordanza dei tempi e dei modi should be applied (and where learners usually do not overcome the interference caused by their L1); and 
c) using implicit subordinate clauses where they are required in the FL: again, they do not overcome the influence of their L1 (in which implicit subordinate clauses are not used, or only to a very limited extent) and instead tend to use explicit subordinates (cf. Lenassi 2004).

In the domain of FL teaching at lower levels (A1, A2 and B1), the teaching of complex-clause syntax seems to have been largely neglected (Mertelj 2005: 5-11, 157218). Particularly in terms of the language-teaching perspective for Romance languages, almost no evidence has so far been found (except Averna and Vedder et al. 2013, which only concerns coordinative syntactic structures). The phenomena among learners encountered by their teachers with regard to complex-clause syntax are not only an issue in the teaching of Romance languages; the same or very similar problems can be found in the teaching of other FLs taught in Slovenian secondary schools (English and German), and, as already stated, by learners with other Slavic linguistic origins.

In the last ten years, under the influence of the CEFR and the "Matura" exam (a state external school-leaving exam that also covers foreign languages), it has been increasingly realised, especially in connection with both written exam assignments (a formal letter and an argumentative essay), that learners have other requirements which are more important than a productive level of almost all grammatical structures in a target FL.

As far as the understanding of syntactically complex clauses is concerned, the learners' results in the Matura exam are not problematic. However, in the tasks used for testing the learners' productive mastery many problems were identified. They ranged from the very limited use of connectives (in fact belonging to lower proficiency levels than required for A1 and A2, according to both the CEFR and Lo Duca 2006), to the appropriate use of tenses and moods (the analysis was only done for Italian, cf. Mertelj 2011) as negative transfer triggered mistakes and errors (problems here are quite well known, since the syntax of Romance complex clauses is objectively difficult for Slovenian learners: it presupposes the speaker's ability to master the highly complex foreign system of tenses and moods). In addition, it was obvious in the written essays that the learners predominantly avoided using complex syntax and used simple connectives, tenses, moods and not those the examiners would expect for an (argumentative) essay. Of course, it is also possible to express arguments and opinions with very simple linguistic means (stemming from the L1), but then such texts are too different from native speakers' texts to be awarded higher scores.

Consequently, there is also less interest in explicitly teaching syntax. This in fact seems to be implicitly encouraged by other requirements, especially writing at intermediate levels. In this respect, we believe there is or might be an interest in some "return" of the explicit teaching of syntax in contact hours or as autonomous learning in secondary schools, and this represents the basis of the first step of our survey: researching the state of the art among learners about their interests, motivational hints, attitudes, and preferences related to complex-clause syntax. 


\section{METHODOLOGY}

This study aimed to explore secondary school learners' opinions about the role of complex-clause syntax in the process of teaching and learning, namely, from slightly different points of view about the topic of this paper. These points of view range from general statements about syntax and skills to very specific ones about goal setting and methodological issues, all in relation to two issues of learning syntax: a) Do learners perceive potential benefits of learning complex-clause syntax for receptive or for productive skills, or perhaps for both, approximately to the same degree? and b) Do learners give priority to more, or to less, systematic learning, with more, or fewer, elements of awareness-building?

Why is there any interest at all in teaching complex-clause syntax, in particular in the opinions of some language-teaching experts? According to the CEFR, such ideas are in line with learners' (presumed) communication needs: the communicative approach includes the development of receptive and productive skills (listening and reading comprehension, speaking and writing) which very soon presupposes some syntactic knowledge to support the understanding of clauses and texts, and soon also for developing productive skills. So far, no studies have explored the pedagogical value of complex-clause syntax instruction in the FL/L2 classroom. Moreover, to date no research has examined the attitudes of learners in this regard. The present study is designed to fill this research void.

Classes in secondary schools typically consist of learners at levels of proficiency ranging from zero or low-level (first-year) to medium-level proficiency (fourth-year) and it is thus a challenge to provide resources to match their learning needs. However, comprehensible input (Krashen 1982) is the first essential component of language learning that might be vitally supported by some necessary meta-linguistic instruction about complex-clause syntax, since complex clauses are present from the very beginning and later gradually enhanced (at higher levels).

However, dealing with texts (which contain complex syntactic patterns) at any proficiency level means that they have to be set at a comprehensible level in order for the input to become an intake (Krashen 1982). Of course, the input also has to be both interesting and relevant to the learner. Everybody is willing to invest effort into things that are perceived as interesting and/or useful, and this means that interest, accordingly, provides the intrinsic motivation for learning (cf. Silvia 2008). We therefore believe that the impact of explicit syntax instruction might support learners' efforts if it is based on their positive attitude to that (theoretical) knowledge which is supposed to efficiently enhance the mastery of an FL/L2. Three hypotheses were formulated, along with seven research statements, all of which refer to secondary school classes:

$\boldsymbol{I}^{\text {st }}$ hypothesis: FL learners believe that explicit knowledge of complex-clause syntax is more important for comprehending texts and less important for producing texts.

(1) Knowledge of complex-clause syntax is primarily essential for text comprehension (listening and reading).

(2) Text comprehension presupposes recognition and understanding of long complex clauses (coordinate and subordinate clauses, connectives, etc.).

(3) Knowledge of complex-clause syntax involves an ability to use connectives and tenses correctly. 
$2^{\text {nd }}$ hypothesis: FL learners believe that knowledge of complex-clause syntax should be imparted systematically and explicitly.

(4) Knowledge of complex-clause syntax is best developed on the basis of a comparison between two languages (the mother tongue and/or a foreign language).

(5) To develop learners' knowledge of complex-clause syntax, it is necessary to systematically guide them by giving them specific complex-clause syntax tasks.

$3^{\text {rd }}$ hypothesis: FL learners believe that knowledge of complex-clause syntax should be gained non-systematically and on the basis of needs stemming from writing tasks.

(6) To develop learners' knowledge of complex-clause syntax, it suffices that a teacher briefly explains the features of syntax as they are encountered (without too many additional explanations and examples).

(7) To develop knowledge of complex-clause syntax, it is essential that a learner engages in independent text production.

In order to explore learners' stances on these issues, data were collected using a questionnaire containing statements (where responses were ranked on a Likert scale) related to the three hypotheses about learning complex-clause syntax. In May and June 2014, the questionnaire was completed by learners in Slovenian secondary schools who take French, Italian or Spanish. Although the research statements used in the questionnaire are primarily based on my own learning and teaching experience over the last 20 years, it must be stressed that they reflect the process of broadly introducing and affirming the communicative approach in the teaching of $\mathrm{FL}$ - an approach which has also been professionally and scientifically researched.

In this way, quite a number of personal experiences are implicitly linked to an analytic confrontation with scientific findings which reveal gradually stronger awareness of the fact that some explicit, although basic, information introduced or dealt with in the FL classroom "theoretically" and overtly (as well as entailed by some "syntactic" tasks according to learning-by-doing principles) is crucial to developing the four abilities in FL teaching. One statement is based on theoretical linguistic studies and analyses with a focus on contrastive aspects with Slovenian, the L1 of most learners, and English as an L2. The statements are all meant for levels from elementary A1 to lower intermediate B1 or, in other words, for classes from the first to the third year of secondary school; some statements follow a slightly mixed order in the questionnaire (they served as control statements).

The subjects participated in the study on a voluntary basis: all teachers of Italian, French and Spanish in those Slovenian public (but also in two semi-private) grammar schools where at least one of these languages is taught were asked to distribute the questionnaires to all learners from the first to the third year. A great number of Italian teachers responded positively, and slightly fewer French and Spanish teachers responded positively.

Nevertheless, the number of all respondents from third year is representative: altogether there were $322(=322)$ from various Slovenian secondary schools, i.e. for Italian as an FL there were 135 respondents, for French as an FL 92 respondents, and for 
Spanish as an FL 95 respondents. These figures are sufficient to represent this generation as a group contributing their opinions to this study. All of the learners responded to the research statements presented above; the results about the general tendencies of Romance language learners, as well as the differences and similarities among them about individual statements and hypotheses are outlined below.

\section{RESULTS AND DISCUSSION}

The data collected via the questionnaire are presented in the following figures, representing the percentage of answers provided by secondary school learners in the third year. The preliminary testing in some classes showed that learners, especially in the first and second year of the secondary school, (surprisingly) complained about being unable to understand some statements - in particular, what syntax is. Therefore, a simple explanation was provided with some examples of paratactic and hypotactic clauses (at the top of the paper, prior to the statements).

\subsection{Syntax and the four skills ( $1^{\text {st }}$ hypothesis)}

The first hypothesis - FL learners believe that explicit knowledge of complex-clause syntax is more important for text comprehension and less for text production - aimed to check learners' opinions and attitudes regarding the role of complex-clause syntax for mastering receptive and productive skills. However, a special emphasis was given to reading comprehension and writing production, as can be deduced from the relevant four research statements (the hypothesis was based on): the first three focus on comprehension, and the fourth on production.

The first research statement (1) is a general one concerning receptive skills (see Fig. 1): the FL learners of Italian, French and Spanish expressed the extent to which they agreed or strongly agreed with the first statement of the questionnaire (1) Knowledge of complex-clause syntax is primarily essential for text comprehension (listening and reading). Such a belief is strongest (when counting the "agree" and "strongly agree" responses together) among the Spanish and French learners, at $88 \%$ and $82 \%$, respectively, whereas the Italian learners are less convinced (78\%), with $22 \%$ of them not agreeing with the first statement.

\begin{tabular}{|l|c|c|c|c|}
\cline { 2 - 5 } \multicolumn{1}{c|}{} & $\begin{array}{c}\text { Disagree strongly } \\
\text { in \% }\end{array}$ & $\begin{array}{c}\text { Disagree } \\
\text { in \% }\end{array}$ & $\begin{array}{c}\text { Agree } \\
\text { in \% }\end{array}$ & $\begin{array}{c}\text { Agree strongly } \\
\text { in \% }\end{array}$ \\
\hline Italian & 3 & 19 & 60 & 18 \\
\hline French & 0 & 19 & 54 & 26 \\
\hline Spanish & 2 & 11 & 68 & 19 \\
\hline
\end{tabular}

Figure 1: “(1) Knowledge of complex-clause syntax is primarily essential for text comprehension (listening and reading)" (in $\% ; \mathrm{N}=135+92+95=322$ ) 
Figure 1 shows that the learners of the three Romance foreign languages involved in the survey agree or strongly agree that knowledge of syntax is essential for comprehension. The result is not surprising, since learners from the third year had previously encountered so many (full or semi-authentic) texts that they had already realised that decoding the meaning of a text can also depend strongly on the comprehension of longer subordinate and coordinate sentence structures.

It is quite surprising that almost one-fifth of the Italian and French group does not agree, and it would be interesting to understand what drives their disagreement: do they rely much more on other aspects to decode a text? Or do they, for example, process the messages of a text with more lexical-based (or other) reading strategies (Jurković 2010 and 2013)? It would also be interesting to find out whether there are, among these learners, mostly those who prefer to adopt a passive, indifferent attitude to the learning of FL, or whether there are also many successful learners among this $20 \%$ share of respondents. With such an attitude, we believe that the respondents implicitly acknowledge the role of complex-clause syntax as an important part of comprehending texts.

The following research statement, (2) Text comprehension presupposes recognition and understanding of long complex clauses (coordinate and subordinate clauses, connectives etc.), was a sort of control question (see Fig. 2) because there are no crucial differences between the previous one and this one (placed seventh in the questionnaire), with a slightly weaker focus on general comprehension and more on understanding whole complex clauses. Results that are not completely similar appeared, but a correlation is evident between the opinions of learners from all three groups related to the first and second research questions (compare Figures 1 and 2):

\begin{tabular}{|l|c|c|c|c|}
\cline { 2 - 5 } \multicolumn{1}{c|}{} & $\begin{array}{c}\text { Disagree strongly } \\
\text { in \% }\end{array}$ & $\begin{array}{c}\text { Disagree } \\
\text { in \% }\end{array}$ & $\begin{array}{c}\text { Agree } \\
\text { in \% }\end{array}$ & $\begin{array}{c}\text { Agree strongly } \\
\text { in \% }\end{array}$ \\
\hline Italian & 4 & 19 & 54 & 23 \\
\hline French & 4 & 13 & 56 & 28 \\
\hline Spanish & 1 & 22 & 57 & 20 \\
\hline
\end{tabular}

Figure 2: “(2) Text comprehension presupposes recognition and understanding of long, complex-clauses (coordinate and subordinate clauses, connectives etc.)" (in \%; N=135+92+95=322)

Thus far, it can be deduced from the first two research statements that the learners from the third year of grammar schools firmly express opinions indicating that complex-clause syntax are related to the comprehension of texts and their (longer) parts, and this implicitly confirms our assumption (besides the $1^{\text {st }}$ hypothesis) that learners in the era of the well-established communicative approach are well aware of the importance of explicit knowledge of syntax for comprehension.

This opinion is equally strongly expressed with the third statement, (3) Knowledge of complex-clause syntax involves an ability to use connectives and tenses correctly in one's own texts, which concerns the value of complex-clause syntax (see Fig. 3): how much does "writing own texts" matter for the development of productive skills? Here 
the learners expressed the strongest agreement with the statement, with percentages (both categories of agreement) ranging from $86 \%$ (Italian learners) and $88 \%$ (French learners) to even $93 \%$ among the Spanish learners. It is more than obvious that complex-clause syntax does matter when it comes to writing skills.

These opinions are supported and implicitly reaffirmed by the last statement in the questionnaire, (7) To develop knowledge of complex-clause syntax, it is essential that a learner independently produces text, where, again, the autonomous writing of one's own text, with or without explicit syntactic support, by the teacher or by themselves, was agreed upon by all learners (see Fig. 7): French learners, at $88 \%$, Spanish learners, at $86 \%$, while only Italian learners were more reluctant, at $73 \%$.

\begin{tabular}{|l|c|c|c|c|}
\cline { 2 - 5 } \multicolumn{1}{c|}{} & $\begin{array}{c}\text { Disagree strongly } \\
\text { in \% }\end{array}$ & $\begin{array}{c}\text { Disagree } \\
\text { in \% }\end{array}$ & $\begin{array}{c}\text { Agree } \\
\text { in \% }\end{array}$ & $\begin{array}{c}\text { Agree strongly } \\
\text { in \% }\end{array}$ \\
\hline Italian & 1 & 13 & 54 & 32 \\
\hline French & 3 & 9 & 47 & 41 \\
\hline Spanish & 0 & 7 & 58 & 35 \\
\hline
\end{tabular}

Figure 3: "(3) Knowledge of complex-clause syntax involves an ability to use connectives and tenses correctly in one's own texts" (in \%; $\mathrm{N}=135+92+95=322$ )

However, we can conclude that the first hypothesis of this study is - surprisingly - not confirmed: most learners convincingly expressed, explicitly and implicitly, their agreement with the importance of knowing complex-clause syntax for productive skills; in addition, not considerably less importance was attributed to its importance for receptive skills (comprehending texts). In fact, it may be concluded that the great majority of learners of all three Romance FL agree that complex-clause syntax is relevant for mastering the foreign language they are learning.

\subsection{Conscious and explicit learning of complex-clause syntax ( $\left(2^{\text {nd }}\right.$ hypothesis)}

With the second hypothesis - FL learners of Romance Languages believe that knowledge of complex-clause syntax should be imparted systematically and explicitly - we tried to elicit two insights on the basis of the learners' opinions: a) how much do they agree with the research statements that all presuppose awareness-development and explicitness in the process of learning complex-clause syntax; and b) to which aspects of the explicit learning do they, if at all, give priority. However, for both insights we can ascertain the opinions. Only with some further research methods (involving elements of qualitative research, e.g. semi-structured interviews, classroom observation, or the like) would we be able to further deepen the insights as to whether such opinions of learners are based on their desired contents and/or techniques in the learning process, or whether such opinions are based on their more or less pleasant experiences with the approaches of their teachers and learning steps regarding the knowledge of syntax.

With the fourth research statement, (4) Knowledge of complex-clause syntax is best developed on the basis of a comparison between two languages (the mother tongue and/ 
or a foreign language), only one aspect was considered (see Fig. 4): a (more or less) systematic presentation of syntax in the light of the contrastive analysis. Here it was not clearly exposed whether or not the learners have an active role; merely the contrastive comparison was the main aspect. About half of the learners of Italian, French and Spanish agreed with this statement, and one-fifth of the Italian and French learners even agreed strongly with it. But we also cannot neglect the relatively large share (more than one-third, 38\%) of Spanish learners who disagreed with the idea of a possible positive effect contrastive analyses or comparison/s with other languages would have on their knowledge of complex-clause syntax. Moreover, the Italian and French learners expressed quite a bit of disagreement (Italian 22\% and French even 28\%) with contrastive aspects in this respect.

\begin{tabular}{|l|c|c|c|c|}
\cline { 2 - 5 } \multicolumn{1}{c|}{} & $\begin{array}{c}\text { Disagree strongly } \\
\text { in \% }\end{array}$ & $\begin{array}{c}\text { Disagree } \\
\text { in \% }\end{array}$ & $\begin{array}{c}\text { Agree } \\
\text { in \% }\end{array}$ & $\begin{array}{c}\text { Agree strongly } \\
\text { in \% }\end{array}$ \\
\hline Italian & 3 & 19 & 60 & 18 \\
\hline French & 11 & 17 & 50 & 22 \\
\hline Spanish & 4 & 34 & 53 & 9 \\
\hline
\end{tabular}

Figure 4: "(4) Knowledge of complex-clause syntax is best developed on the basis of a comparison between two languages (the mother tongue and/or a foreign language)"

(in $\%$; $\mathrm{N}=135+92+95=322$ )

The fifth research statement, (5) To develop learners'knowledge of complex-clause syntax, it is necessary to systematically guide them by giving them specific complexclause syntax tasks, was linked to the second hypothesis and involved two aspects (see Fig. 5) of actively practising syntax: a) the systematic, not occasional, practice and use of complex syntactic patterns, where b) learners do have an active role, they are the "doers" of exercises and tasks, so grammar is a tool in the FL Italian, French and Spanish classrooms. Learners from all three linguistic groups agreed or strongly agreed with statement (5); such belief is strongest (by counting the "agree" and "strongly agree" responses together) among the French learners, with $90 \%$, Spanish, with $86 \%$ and less with learners of Italian where one-fifth agreed strongly, but one-fifth also disagreed with the concept of active learning-by-doing (see $23 \%$ vs. $23 \%$ in Fig. 5).

\begin{tabular}{|l|c|c|c|c|}
\cline { 2 - 5 } \multicolumn{1}{c|}{} & $\begin{array}{c}\text { Disagree strongly } \\
\text { in \% }\end{array}$ & $\begin{array}{c}\text { Disagree } \\
\text { in \% }\end{array}$ & $\begin{array}{c}\text { Agree } \\
\text { in \% }\end{array}$ & $\begin{array}{c}\text { Agree strongly } \\
\text { in \% }\end{array}$ \\
\hline Italian & 1 & 22 & 54 & 23 \\
\hline French & 1 & 9 & 53 & 37 \\
\hline Spanish & 5 & 9 & 72 & 14 \\
\hline
\end{tabular}

Figure 5: "(5) To develop learners' knowledge of complex-clause syntax, it is necessary to systematically guide them by giving them specific complex-clause syntax tasks" (in \%; $\mathrm{N}=135+92+95=322$ ) 
Considering the beliefs about the two research statements, it can be concluded that the second hypothesis of this study is - again, surprisingly - confirmed: the great majority of learners convincingly expressed their agreement that knowledge of complexclause syntax should be imparted systematically and explicitly, with some reluctance shown by approximately one-fifth of the learners, who obviously would give preference to an implicit and accidental, non-systematic way of gaining the knowledge and practice of complex-clause syntax. The only disagreement clearly expressed by quite a few learners (at least one-fifth) among all three linguistic groups was that the contrastive aspects were considered to be less relevant in the process leading towards mastery of complex-clause syntax.

\subsection{Individual learning and acquisition of complex-clause syntax ( $3^{\text {rd }}$ hypothesis)}

With the third hypothesis - FL learners of Romance languages believe that knowledge of complex-clause syntax should be gained non-systematically and on the basis of needs stemming from concrete writing tasks - we tried to test the learners' opinions regarding their strength as compared to what was implicitly expressed in the second hypothesis (namely, where the idea that knowledge of complex-clause syntax should be imparted systematically and explicitly was supported by approximately $80 \%$ of the respondents); this was not the case with about one-fifth of them.

In the two research statements ( 6 and 7$)$ the goal was obvious: to gather opinions about non-systematic learning when "a syntactic problem" is encountered after a communication need arises. Also in this case two insights were targeted: a) how much do learners agree with occasional awareness-building (when the syntactic phenomena are made explicit); and b) how do they feel about obtaining such information by themselves when faced with a school and/or home assignment of writing a text in which the need for some complex-clause syntax is perceived.

The first research statement in this series regarding the last hypothesis, (6) To develop learners' knowledge of complex-clause syntax, it is enough that a teacher briefly explains the features of syntax as they are encountered (without too many additional explanations and examples), has a focus on the occasional presentation or brief occasional explanations of the encountered syntactic features, where learners of Italian, French and Spanish do not have an active role in the process (see Fig. 6). The learners of French and Italian disagreed or strongly disagreed with the statement. Such a belief is agreed to the strongest by the French learners ( $72 \%$, counting the "disagree" and "strongly disagree" responses together); about two-thirds of Italian learners (62\%) hold the same opinion, but more than one-quarter (together 28\%) agree with occasionally dealing with complex-clause syntax. Among the Spanish learners, this attitude is even stronger (36\%). With such opinions, the learners strongly confirmed their answers given in the framework of the second hypothesis (see Figures 4 and 5). 


\begin{tabular}{|l|c|c|c|c|}
\cline { 2 - 5 } \multicolumn{1}{c|}{} & $\begin{array}{c}\text { Disagree strongly } \\
\text { in } \%\end{array}$ & $\begin{array}{c}\text { Disagree } \\
\text { in } \%\end{array}$ & $\begin{array}{c}\text { Agree } \\
\text { in } \%\end{array}$ & $\begin{array}{c}\text { Agree strongly } \\
\text { in } \%\end{array}$ \\
\hline Italian & 27 & 45 & 24 & 4 \\
\hline French & 41 & 31 & 26 & 2 \\
\hline Spanish & 14 & 50 & 31 & 5 \\
\hline
\end{tabular}

Figure 6: “(6) To develop learners' knowledge of complex-clause syntax, it is enough that a teacher briefly explains the features of syntax as they are encountered (without too many additional explanations and examples)" (in $\% ; \mathrm{N}=135+92+95=322$ )

The second research statement in the questionnaire, (7) To develop knowledge of complex-clause syntax, it is essential that a learner engages in independent text production, implied writing at school or at home, in an environment where a learner is autonomous while writing a text (see Fig. 7). It focuses on learners' decisions about looking up syntactic information according to their communication needs, an undertaking which presupposes active participation in their own writing process - either the learners already have the necessary syntactic knowledge or they look up such information themselves in model texts or in grammar books (these avenues should be further researched, along with learners' communication needs and their ability to successfully find such information). Again, the learners of French and Spanish agreed or strongly agreed with the last statement (both approaching 90\%). In this way, they also expressed the principle of learning-by-doing that has been fostered by most textbooks since the introduction of the CEFR and which is consequently probably already well-established among today's learners of foreign languages.

The learners of Italian, on the other hand, were again less convinced about autonomous writing and, again, one-quarter of them (see Fig. 7) seemed to prefer not to do a writing assignment or explicitly did not believe they could practise complex-clause syntax in this way. They seemed to have other needs or preferences, and only with another survey can more precise answers be found among them. There is again a general doubt about whether perhaps the weaker learners expressed their discontent with an autonomous writing assignment in this way, or whether this reflected their general attitude to an active role in the FL classroom.

\begin{tabular}{|l|c|c|c|c|}
\cline { 2 - 5 } \multicolumn{1}{c|}{} & $\begin{array}{c}\text { Disagree strongly } \\
\text { in \% }\end{array}$ & $\begin{array}{c}\text { Disagree } \\
\text { in \% }\end{array}$ & $\begin{array}{c}\text { Agree } \\
\text { in \% }\end{array}$ & $\begin{array}{c}\text { Agree strongly } \\
\text { in \% }\end{array}$ \\
\hline Italian & 3 & 24 & 54 & 19 \\
\hline French & 2 & 10 & 53 & 35 \\
\hline Spanish & 0 & 14 & 63 & 23 \\
\hline
\end{tabular}

Figure 7: "(7) To develop knowledge of complex-clause syntax, it is essential that a learner engages in independent text production" (in \%; $\mathrm{N}=135+92+95=322$ ) 
The answers about beliefs concerning the two research statements of the third hypothesis suggest that this hypothesis is also partly confirmed (albeit in apparent contrast with the also confirmed second hypothesis). Again, the great majority of learners of Romance languages quite convincingly expressed their agreement that knowledge of complex-clause syntax should be gained non-systematically and on the basis of needs stemming from concrete writing tasks, with some evident reluctance with the last statement from the learners of Italian, who obviously did not find relevant an occasional, non-systematic way of gaining knowledge of and practicing complex-clause syntax.

Because there is much "overlap" between the second and third hypotheses, particularly in the sense that both were confirmed, it should be noted that the learners of all three linguistic groups obviously did not want to exclude either of the two aspects included in the two hypotheses. Hence, systematic and conscious learning leading towards knowledge of complex-clause syntax as well as its usage in writing assignments (whether spontaneously or searched for if needed) was confirmed as being highly important to learners of Romance languages as an FL. They agree that both aspects regarding complex-clause syntax are very important for the quality of their linguistic production.

About one-quarter to one-third of the respondents (depending on individual research statements for certain specific aspects) were - in the last two hypotheses - against the mainstream. However, this would imply (if in further research the reason can be found in the methodological approaches or techniques, not in learners' passive or even work-evading attitude, or even indifference towards FL learning) that some other ways of dealing with writing assignments and syntactic needs should be developed, and such learners - be they "weaker" or "stronger" in foreign languages - should be supported in another way.

That being said, also in this case we could find out the learners' opinions for all the hypothesised statements; only by employing some more research methods (semistructured interviews with learners and teachers, classroom observation, or the like) can further findings be reached - in particular, pedagogically-driven ones about the desired contents and techniques in the learning process, or ones pertaining to valuable experiences with learning steps regarding complex-clause syntax.

\section{CONCLUSIONS AND FURTHER DISCUSSION}

The main research topic of this article was learners' opinions about knowledge of complex-clause syntax, more specifically, about its relevance for developing the four skills and its explicit or implicit application in the learning process leading towards productive skills (writing). Learners' opinions about this topic can provide important indications about their perceptions of complex-clause syntax as well as implicit insights into their motivation and communication needs.

The results showed that the majority of learners from the third year of secondary schools seem to be well aware of the important role of complex-clause syntax for both receptive and productive skills, and these learners believe the role is even stronger for the latter skills (the $1^{\text {st }}$ hypothesis, FL learners believe that explicit knowledge of complex-clause syntax is more important for comprehending texts and less for producing 
texts, was not confirmed). In addition, they showed a clear preference for systematic - that is, more explicit than implicit - dealing with complex-clause syntax in class (the $2^{\text {nd }}$ hypothesis, FL learners believe that knowledge of complex-clause syntax should be imparted systematically and explicitly, was confirmed). They also seem to be aware of the benefits that good knowledge of complex-clause syntax brings in terms of higher proficiency in writing skills (in the questionnaire the relation to speaking skills was omitted), as the $3^{\text {rd }}$ hypothesis, FL learners believe that knowledge of complex-clause syntax should be gained non-systematically and on the basis of needs stemming from concrete writing tasks, can be regarded as partly confirmed.

For most of the seven research statements included in the questionnaire (and belonging to the three hypotheses), the preference for systematic complex-clause syntax development and knowledge was, with a large majority, clearly corroborated by student opinions, although in some cases they were less convinced. For example, the learners were surprisingly strongly aware of their disinclination for contrastive comparisons. They did not find them very relevant for developing knowledge of complex-clause syntax or a sort of useful tool for their productive skills (writing assignments).

This is in clear contrast with (mostly psycholinguistic) applied experts and linguistic experts as well as many researchers in the awareness-raising field (Larsen-Freeman 2000 and 2003; van Lier 2001) who believe in the positive value of it; on the other hand, not much research has so far examined if and how the awareness about language/s, of a possible positive transfer and warnings by negative transfer between languages, positively influences language production in the second language, and especially not of how it encourages or reduces the use of complex-clause syntax. Awareness-raising here, however, cannot be achieved without explicitly dealing with it in the FL classroom. In order for learners to become (more) successful lifelong learners, we believe they should also be equipped with such strategic knowledge or knowledge about complex-clause syntax as a powerful tool (how to use it) as a means for upgrading their general, especially productive, mastery of the foreign language/s they are learning.

\subsection{Potential benefits and disadvantages}

Although the questionnaire responses do not reveal whether complex-clause syntax is taught and, if so, according to which concept/s, or whether the responses perhaps expressed learners' desires and general opinions (based on teaching approaches or methods in the learning of other FL), it is clear that explicit teaching of complexclause syntax in the FL classroom is seen as beneficial, as confirmed by the learners' responses. In addition to contributing to the development of the four skills by way of general language mastery, some theoretical knowledge is perceived as useful, in particular when related to writing assignments. Yet the student responses indicate that they are aware of the beneficial effect of complex-clause syntax on their writing skills, and it cannot be excluded that they would also have expressed favourable opinions about speaking skills if they had been asked about them.

Despite some benefits complex-clause syntax might bring into the FL classroom, we should - maybe primarily - also be aware of the problems this could cause, in particular 
for some learners. Importantly, we should consider pedagogical options for how to appropriately relieve the cognitive load, teach not only to know, but also to use complexclause syntax to facilitate comprehension and to give support for productive skills, and thereby enhance the learning process. First, learners seem to agree that complex-clause syntax might have an important (and in some cases even a decisive) role, but there are many linguistic topics to be developed in an FL classroom on the path towards a good command of a foreign language.

Accordingly, a possible solution would be to constantly ask learners to be as active as possible while dealing with syntax, and accept it as a sort of benefit (when dealing with it at home and in the classroom) for productive writing assignments. However, a challenge remains: how to make sure that all learners will have completed the complexclause syntax load at home (for example, if it is made available through online learning platforms), while at the same time maintaining their intrinsic and extrinsic motivation.

Second, the learners did not reveal a keen interest in contrastive aspects as a possible technique for guiding them towards better command of complex-clause syntax when a writing task is assigned. In the past, many experts believed that (strongly cognitive) contrastive approaches solve most learning-related problems (in this respect) and that any other complex-clause syntax approaches are less efficient and/or at least more time-consuming. But teaching praxis also seems to show that by imitating sentences and texts, if they are relevant models, learners can achieve "accelerated" text proficiency. However, we lack research evidence regarding both approaches (bilingual, contrastive and/or "imitative").

As a result of these doubts, more research should be conducted, along with experimenting with a variety of tasks that might be beneficial for the goals; for example, bilingual tasks focused on a comparison between languages contribute to a smaller cognitive load. As stated by Swaffar and Vlatten (1997), an absence of comprehension may cause frustration and increase the level of language learning anxiety, but a "safe" environment (which is supposed to be enhanced by "contrastive" and bilingual approaches) should have a positive effect, resulting in upgraded language knowledge and the mastery of productive skills.

\subsection{Limitations and perspectives}

The research was conducted among learners in the third year of secondary school and participation in the questionnaire was obligatory. Except for a few individual cases of learners showing discontent (by circling the same answers for all statements), the vast majority of learners was evidently interested in and keen on responding (some also added expressions of interest below the statements). Hence, the serious participation of the respondents is certainly not a significant limitation of this study. The remarks did not provide any information regarding differences in attitudes to complex-clause syntax among different levels of pre-existing language ability.

However, an interesting research challenge could involve exploring whether the "contrastive plus bilingual" vs. "imitative" approach (albeit both in a very systematic way) is in any way related to the pre-existing language ability of learners. In addition, 
empirical research would have to explore the efficiency of learning through the use of "contrastive" techniques as compared to the imitation and "creative" elaboration of model texts, with the time spent on each approach being correlated.

Some future empirical studies could also aim to indicate possible answers to questions pertaining to the applied field of foreign language teaching methodology meant for the process of complex-clause syntax learning and also for testing after the completion of lower levels. Such additional testing should focus on examining productive knowledge, as well as on the awareness of some relevant contrastive problems as a contribution to effective knowledge. Another questionnaire for learners might enquire into the role of techniques for teaching complex-clause syntax and their experiences and perceptions of the proper mastery of an FL.

\section{References}

AVERNA, Carmelo/Ineke VEDDER (2013) "La coordinazione sintattica nelle produzioni scritte in italiano L2 ed L1." In: M. Rükl et al. (eds), Contesti di apprendimento di italiano L2. Firenze: Cesati, 15-26.

BATSTONE, Rob (1994) Grammar (Language Teaching: a Scheme for Teacher Education). Oxford: Oxford University Press.

BOLITHO, Rod et al. (2003) "Ten questions about language awareness." ELT J 57/3, 251-259.

BOSTIČ, Nina (2011) "Model essay as a feedback tool in task 2 of the IELTS writing exam instruction for Slovene students." ELOPE 8, 91-105.

BYRNES, Heidi et al. (2010) "Realizing advanced foreign language writing development in collegiate education: curricular design, pedagogy, assessment." The Modern Language Journal 94/Supplement, 1-235.

Common European Framework of Reference for Languages: Learning, Teaching, Assessment (2001). Cambridge: Cambridge University Press.

CORREIA, Clara N. et al. (2013) Descrições e contrastes - tópicos de gramática portuguesa com exemplos contrastivos eslovenos $=$ Opisi in primerjave - poglavja iz slovnice portugalskega jezika s kontrastivnimi ponazoritvami v slovenščini. Ljubljana: Znanstvena založba Filozofske fakultete.

GRANGER, Sylviane (2009) "The contribution of learner corpora to second language acquisition and foreign language learning." In: K. Aijmer (ed.), Corpora and Language Teaching. Amsterdam/Philadelphia: John Benjamins, 13-30.

HAWKINS, John/Michael McCARTHY (2010) "Introduction to English Profile Journal." English Profile Journal 1/1, 1.

HÖPPNEROVÀ, Vera (2013) "Zur morpho-syntaktischen Charakteristik der Handelskorrespondenz." Fachsprache, International Journal of Specialized Communication 3/4, 118-139.

JURKOVIĆ, Violeta (2010) "Language learner strategies and linguistic competence as factors affecting achievement test scores in English for specific purposes." TESOL journal 1/4, 449-469. 
JURKOVIĆ, Violeta (2013) "Effect of strategy based instruction on achievement test scores in a mixed language ability group of ESP learners." Ibérica 25, 195-214.

KRASHEN, Steven D. (1982) Principles and Practice in Second Language Acquisition. Oxford: Pergamon Press.

LARSEN-FREEMAN, Diane (2000) Techniques and Principles in Language Teaching. Oxford: Oxford University Press.

LARSEN-FREEMAN, Diane (2003) "Using Native and Non-Native Texts to Promote Grammatical Awareness, Develop Skills, and Enhance Attitudes towards the Study and Teaching of Grammar." In: L. Dilin/P. Master (eds), Grammar Teaching in Teacher Education. Alexandria, VA: TESOL, 101-109.

LENASSI, Nives (2004) "Implicitne glagolske konstrukcije: problem njihovega poučevanja v okviru poslovnega italijanskega jezika." Vestnik 38/1-2, 173-195.

LO DUCA, Maria (2006) Sillabo di italiano L2. Per studenti universitari in scambio. Roma: Carocci.

LU, Xiaofei (2011) "A Corpus-Based Evaluation of Syntactic Complexity Measures as Indices of College-Level ESL Writers' Language Development." TESOL Quarterly $45,36-62$.

MARKIČ, Jasmina (2010) El verbo en español: aspectos teóricos de la morfosintaxis del verbo español. Ljubljana: Filozofska fakulteta, Oddelek za romanske jezike in književnosti.

MERTELJ, Darja (2005) "Učitelji in poučevanje skladnje." Vzgoja in izobraževanje $36 / 1,44-51$.

MERTELJ, Darja (2011) "Some aspects and case studies about teaching Italian complex-clause syntax to Slovenian learners." Filolog III, 179-191.

MIKLIČ, Tjaša (1992) "Tendenze nella scelta delle forme verbali italiane in testi prodotti da apprendenti sloveni: in cerca di spie dell'interferenza." In: B. Moretti/D. Petrini/S. Bianconi (eds), Linee di tendenza dell'italiano contemporaneo. Roma: Bulzoni, 475-492.

MIKLIČ, Tjaša (2003) "Interpretazione della funzione testuale dei paradigmi verbali italiani. Tentativo di un modello d'analisi integrata." In: M. Giacomo-Marcellesi/A. Rocchetti (eds), Il verbo italiano: Studi diacronici, sincronici, contrastivi, didattici. Roma: Bulzoni, 553-570.

MIKLIČ, Tjaša/Martina OŽBOT (2007) "Teaching the uses of Italian verb forms to Slovene speakers." Linguistica 47, 65-76.

ORTEGA, Lourdes (2012) Interlanguage complexity: A construct in search of theoretical renewal. Cited in: Vyatkina, Nina (2012) "Specific Syntactic Complexity: Developmental Profiling of Individuals Based on an Annotated Learner Corpus." The Modern Language Journal 97/S1, 11-30.

SAMARDŽIĆ, Mila (2006) Od rečenice do teksta. Uvod v sintaksu italijanske složene rečenice. Podgorica: Univerzitet Crne Gore, Filozofski fakultet.

SCHLOBINSKI, Peter (2014) "Kohäsionsmittel und Textstrukturen." Der Deutschunterricht $\mathrm{LXVI} / 3,39-48$.

SILVIA, Paul J. (2008) "Interest, the curious emotion." Current Direction in Psychological Science 17, 57-60. 
SWAFFAR, Janet/Andrea VLATTEN (1997) "Sequential Model for Video Viewing in the Foreign Language Classroom." The Modern Language Journal 81/2, 175-188. VAN LIER, Leo (2001) "Language Awareness." In R. Carter/D. Nunan (eds), The Cambridge Guide to Teaching English to Speakers of Other Languages. Cambridge: Cambridge University Press, 160-165.

VUČO, Julijana (2012) O učenju jezikov: pogled v zgodovino glotodidaktike: od pradavnine do druge svetovne vojne. Transl. N. Colnar. Ljubljana: Znanstvena založba Filozofske fakultete.

VYATKINA, Nina (2012) "Specific Syntactic Complexity: Developmental Profiling of Individuals Based on an Annotated Learner Corpus." The Modern Language Journal, 97/S1, 11-30.

\section{Abstract \\ SYNTAX MENTIONED SEVEN TIMES IN THE CEFR - AND HOW MANY TIMES AT SCHOOL, IN FOREIGN LANGUAGE CLASSROOMS?}

In the teaching of foreign languages, complex-clause syntax does not seem to have had an established role over the last 20 years, especially within the communicative approach and, of course, the CEFR. It was previously part of methods which stressed formal approaches to foreign languages and their being taught, but not of natural, acquisition-based methods. With the communicative approach, two important premises were introduced: authentic texts and grammar as a tool when necessary. This is one probable reason why explicit, complex-clause syntax is hardly mentioned in the CEFR, even though it is implicitly present in descriptors, even though it is particularly recognisable in those for writing skills, and even though we know that it can be used for all four skills, as well as to guide learners towards some self-directed learning about language features.

To date, in the era of the communicative approach, not much is known about the role of complex-clause syntax in foreign/second language classrooms, in particular from the learners' viewpoint. In order to bridge this research gap, the paper analyses a questionnaire among learners in secondary schools that looked at their perspectives regarding the (possible) role of syntax. The examined aspects consider its role for the four skills, and the benefits of knowing syntax; implicitly, the paper touches on some affective factors and related methodological approaches, along with problems concerning the teaching of syntax. The findings are based on quantitative data; an evaluation of the need for complex-clause syntax is included, and some pedagogical implications are presented.

Keywords: complex-clause syntax, foreign language learning, writing skills, Romance languages, learners' perspectives. 


\section{Povzetek \\ SEDEMKRAT SKLADNJA V SEJO - IN KOLIKO KRAT V ŠOLI, PRI POUKU TUJIH JEZIKOV?}

Za področje poučevanja tujih jezikov se zdi, da $\mathrm{v}$ zadnjih dvajsetih letih poučevanje večstavčne skladnje nima (več) svojega mesta, zlasti ne znotraj meja komunikacijskega pristopa, in seveda SEJO. Pred tem je bilo del metod, ki so poudarjale na oblikah osredinjene pristope $\mathrm{k}$ tujim jezikom in $\mathrm{k}$ njihovemu poučevanju, toda nikdar del naravnih, na usvajanju utemeljenih metod. S komunikacijskim pristopom, ki ga je utrdil SEJO, sta bili uvedeni dve pomembni področji: avtentična besedila in slovnica kot orodje, ko je potrebno. Morda je prav to razlog, da je eksplicitna, večstavčna skladnja v SEJO komaj kje omenjena, čeprav je implicitno prisotna $\mathrm{v}$ opisnikih, zlasti v tistih za pisne zmožnosti. Obenem vemo, da je uporabna za vse štiri zmožnosti, kot tudi za vodenje učencev pri samostojnem učenju o jezikovnih prvinah in pojavih.

Doslej, v obdobju komunikacijskega pristopa, ni veliko znanega o vlogi večstavčne skladnje pri pouku tujih/drugih jezikov, zlasti ne s stališča učencev. Da bi zapolnili to raziskovalno vrzel, se prispevek osredotoča na analizo vprašalnika med učenci $\mathrm{v}$ gimnazijah glede njihovih pogledov na (možno) vlogo večstavčne skladnje, in sicer na njeno vlogo pri razvijanju štirih zmožnosti in na prednosti znanja skladnje; implicitno se prispevek dotakne tudi afektivnih dejavnikov in z njimi povezanih metodoloških pristopov in tudi problemov glede učnih vsebin. Ugotovitve temeljijo na kvantitativnih podatkih, ovrednoti se potrebnost poučevanja večstavčne skladnje, predstavljene pa so tudi nekatere pedagoške implikacije.

Ključne besede: večstavčna skladnja, učenje tujih jezikov, pisna zmožnost, romanski jeziki, stališča učencev. 